\title{
Green Consciousness of Consumers in a Developing Country: A Study of Egyptian Consumers
}

\author{
Passent Tantawi \\ Brunel University \\ E-Mail: ptantawi@hotmail.com \\ Nicholas O’Shaughnessy \\ University of London \\ E-Mail: n_o_shaughnessy@hotmail.com \\ Khaled Gad \\ Brunel University UK and Arab Academy for Science \\ E-Mail: khalid.Gad@gmail.com \\ Mohamed Abdel Salam Ragheb \\ Florida Institute of Technology, Melbourne, Florida, and Arab Academy for Science \\ Technology and Maritime Transport \\ E-Mail: raghebmm@aast.edu
}

\begin{abstract}
The last three decades have seen a progressive increase in worldwide environmental consciousness due to rising evidence of environmental problems. Environmental protection is increasingly becoming a necessity and part of a bigger agenda in the urbanising world of developing countries. Given the increasing deterioration of the environment, Egypt as in most developing countries should prevent pollution and preserve its natural resources. Egyptian consumers are just at the stage of green awakening. The Egyptian government and companies should respond to the green challenge by knowing whether or not Egyptian citizens are concerned about green issues. Environmental attitudes constitute a significant part of environmental consciousness. Therefore, this paper empirically investigates the attitude of Egyptian consumers towards the environment in general. A survey was developed and administered across Egypt. A total of 122 Egyptian consumers responded and completed the questionnaire. Results contradict the traditional wisdom that
\end{abstract}


environmental concern is a luxury afforded by only the wealthy and shed a light upon the possibility of going green in Egypt. This will help the Egyptian government better understand consumers' level of concern about the environment, develop effective environmental policies required to achieve sustainability and reinforce green purchase through legislation. Moreover, companies will have insight about how to profile green consumers in Egypt, and better develop green marketing messages that will functionally and emotionally appeal to their target customers.

Keywords: Pro-environmental Attitude, Green Marketing, Environmental Consciousness

\section{INTRODUCTION}

Over many centuries, the issue of environmental preservation has been on the top of the agenda of global and international concerns as one of the most important issues at both the national and international levels (MSEA, 2005). Billions have been spent on both national and international conservation programs, pollution control and prevention efforts, and the protection of endangered species and resources (Lee et al., 2005). Concern about the impact of economic activity on the environment has been an issue of varying importance on society's agenda. The discipline of marketing is one of many that has been affected by the increasing environmental concern, first in the early 1970s, then in the late 1980s/early 1990s (Peattie, 1995), and more recently in the late 1990s (Schlegelmilch et al., 1996; Menon and Menon, 1997; Peattie and Crane, 2005).

Despite the environmental attention in the 1970s, it has been only in the late 1980 s that the idea of green marketing has really emerged. Early academic treatments of green marketing have tackled the rapid increase in green consumerism at that time as heralding an inevitable shift in consumption towards greener products (Prothero, 1990; Vandermerwe and Oliff, 1990). The engine driving green consumer demand and green marketing can be broadly termed as the 'green movement' (Pierre and Prothero, 1997). As the 1970s were known for 'environmentalism', the 1990's were known for 'green' where the main emphasis was on the underlying problems with the social, economic, technical or legal systems rather than on the environmental problems only. Moreover, the focus was on global rather than on local environmental problems. The environmentalist movement's message focused on a 'one way street' view of the impact of society and business on the environment. However, the new green movement has been more actively promoting the other side of the equation which is the impact of the environment on society and business. Green goes beyond purely environmental issues to cover issues of public health, nationalism, trade, 
economic development and political power (Peattie, 1992). The term 'green' is typically used interchangeably with 'pro-environmental' (Shrum et al., 1995) and 'environmental' (Mostafa, 2007a). However, because of differences in definitions of the environment, the term is necessarily imprecise but it is simply used to indicate concern with the physical environment (air, water, land) (Shrum et al., 1995).

Concern about the environment has increased steadily among the public of industrialised world and has become of primary concern. This concern has not been limited to industrialised nations such as Germany (Pierre and Prothero, 1997) and US (Ottman, 1998) but extended to other less industrialised nations such as India, Philippines, and Turkey. These less industrialised countries have experienced high levels of concern about environmental issues such as water and land pollution and have come to believe that deterioration of the environment would be detrimental to public health (Peattie, 1992). Because many environmental problems are associated with human consumption, the problem of conservation has been brought down to the consumer level. Accordingly consumers are inclined to take some responsibility to reduce environmental damage through the consumption of environmentally friendly products. In turn, this has its impact on marketers of consumer products and organisations because they have to respond to this green challenge (Peattie, 1992; 1995; Ottman, 1998; Paladino, 2005; Abdul-Muhmin, 2007). This will also affect policy makers and researchers who seek to influence consumers' behavioural change in order to address environmental issues (Clark et al., 2003).

Previous empirical evidence emphasised that environmental concern is a major factor in the consumer decision making (Zimmer et al., 1994; Wagner, 1997; Ottman, 1998). Determining what people know about the environment, how they feel about it, and what actions they take that may help or harm the environment is critical to establishing the sustainability of a community. This will create a strong national environmental movement that will conserve the environment by solving environmental problems (Sudarmadi, 2001). A progressive degradation of nature, widespread pollution, and ineffectiveness of technical solutions used to cope with environmental problems are often more severe in developing countries such as in Egypt (Hopkins et al., 2001; MSEA, 2005). Therefore, a need to preserve and protect the environment is more urgent. The resolution of environmental problems depends more on the attitudes of the general public than on the knowledge of experts (Graham, 1994). Consequently, to ensure cooperation between citizens and to initiate a successful environmental policy or educational program in developing nations, it should be of primary interest for marketers and policy makers to understand and learn 
about the level of consumers' green consciousness. Researchers should also develop measures related to green consciousness and test their validity in the Egyptian context (Furman, 1998; Tantawi et al., 2006a; b; Abdul-Muhmin, 2007; Mostafa, 2007a; b).

\section{OBJECTIVE OF THE STUDY}

The increase in environmental consciousness has a profound effect on consumer behaviour, with the green product market expanding at a remarkable rate. Evidence suggests that a growing number of consumers in the US and Western Europe are becoming more environmentally responsible in terms of their personal habits and lifestyles (Shamdasani et al., 1993; Ottman, 1998). Very little attention has been given to the area of consumers' green consciousness in the Middle East (Abdul-Muhmin, 2007; Mostafa, 2007a; b). Measures devised in Western countries have not been tested for validation especially in Egypt, a country that is a host to many environmental problems and whose consumers are beginning to develop awareness of the importance of going green (Rice, 2006; Tantawi et al., 2006a; b; Mostafa, 2007a; b). Some authors confirmed that attitude towards the environment is considered to be the most important predictor of consumers' green consciousness (Bohlen et al., 1993; Bohlen, 1994; Rannikko, 1996; Schlegelmilch et al., 1996). Therefore, this study empirically investigates the attitude of Egyptian consumers towards the environment in general i.e. consumers' concern about the quality of the environment.

Tantawi et al. (2006a; b) found that Egyptian consumers perform several actions that harm their environment such as harmful waste disposal, although they perceive their environment to be highly polluted. Moreover, Egyptian consumers indicate that they require their government to enhance their standard of living before focusing on going green. This was previously supported by Hopkins and Mehanna (2000) who stated that Egyptian consumers rank first their economic concerns then environmental concerns. Inglehart (1990) and Buttel (1992) argued that environmental concern is a set of values that develop among wealthy people once their basic needs of food and safety have been met. This leads to the prediction that developing countries like Egypt should be less concerned about the environment than the western countries (Mostafa, 2007a). Therefore, it is hypothesised that:

H1: Egyptian consumers are not concerned about the quality of the environment. 


\section{THE INCREASED CONCERN FOR GREEN MARKETING}

Green marketing is a holistic and responsible strategic management process that identifies, anticipates, satisfies and fulfils stakeholder needs, for a reasonable reward, that does not adversely affect human or natural environmental well-being (Charter, 1992). Prothero (1990) argued that green marketing management extends societal marketing to embrace society's concern about the natural environment. Karna et al. (2003) emphasised that the green agenda has now been integrated into mainstream marketing literature. Green marketing (Peattie, 1992; Pierre and Prothero, 1997; Ottman, 1998) has been referred to as: environmental marketing (Coddington, 1993; Peattie, 1992; 1995); greener marketing (Charter and Polonsky, 1999); and sustainable marketing (Fuller, 1999).

Companies from a variety of industries are responding to consumer demand for green products. Consumer researchers have identified differences in consumers according to the degree of their 'greenness'. Consumers have become more demanding, and satisfying their demands is one of the external pressures to greening (Ottman, 1998; Shelth et al., 1999; Mackenzie, 2000; Polonsky and Rosenberger III, 2001). Green consumers in the West are as active as ever, creating opportunities for innovative products with an environmental edge (Ottman, 1998; Mackenzie, 2000). Marketers may want to identify these environmentally conscious consumers in order to effectively target certain markets for their green products (Bohlen et al., 1993; Schlegelmilch et al., 1996; Wagner, 1997; Diamantopoulos et al., 2003).

Greener consumers will look to direct themselves towards greener products and firms. The challenge for the firm is to provide the option and the benefits (Charter, 1992). In their effort to respond to the consumer demand for a healthier environment, companies engage in green marketing. A significant niche market has emerged for green products (Pierre and Prothero, 1997). Stores such as Body Shop have grown into major concerns by selling environmentally- friendly skin and hair care products. Moreover, countries like Germany with relatively tough environmental legislation have developed strong clean-technology sectors (Pierre and Prothero, 1997). On the other hand, some companies have expressed their concern for the environment but it has not been the principal motivation for going green. Reasons could be reactive responses to pressures from government legislation, non-governmental organisations (NGOs), customers, and other stakeholders (Saha and Darnton, 2005).

Environmental problems have been the key driving force of green marketing. Over the coming three decades, new and emerging threats, including climate change, introduced species, uncontrolled expansion of cities, and pollution from cars and 
industry, are likely to aggravate levels of poverty, environmental decline and health problems (Beaumont et al., 1993; UN Chronicle, 2002). The evidence of environmental crises is quite obvious. Among the important crises are: acid rain, deforestation, desertification, ozone depletion, global warming, and large scale disasters (Beaumont et al., 1993). Examples of these large scale disasters are: the release of dioxin after a major chemical explosion at Givandan's plant at Seveso in 1976; a leak of poisonous fumes from the Union Carbide's plant at Bohapal in India in 1984; the explosion at the soviet nuclear plant at Chernobyl in 1986; the 'NIMBY' (not-in-my-back yard) syndrome of the 1988 voyage of Karin B barge which led to the release of toxic organic substances; the 1989 oil spills from the Exxon Valdez near Alaska; oil releases in Kuwait during the gulf war in 1990; the 1992 Aegean sea oil spillage off the north western coast of Spain (Beaumont et al., 1993); the 2002 sinking of Prestige oil tanker on the coast of Galicia, Spain (Green Peace International, 2006); the 2004 destructive earthquake and Asian Tsunami, where the hardest hits were Indonesia, Srilanka, India, Thailand, and the Maldives (Brunner, 2006); and the 2006 earthquake of south of Java in Indonesia (Infoplease, 2006).

Companies should realise that environmental problems are not only important but also different than in the past. They must not only enhance the quality of their goods and services but also the quality of the environment. Environmental issues are no longer regulatory issues but rather strategic business issues. Therefore, a different approach is required, precisely; a proactive anticipatory approach rather than a reactive approach in dealing with environmental issues (Azzone and Bertele, 1994; Meyer, 2000).

\section{SUSTAINABILITY}

The concept of combining environmental concern (which traditionally involves encouraging conservation) with the discipline of marketing management (which aims to stimulate and facilitate consumption) can appear somewhat paradoxical. Sustainability is the key stone of the green marketing philosophy, which resolves this apparent paradox. A sustainable approach to consumption and production involves enjoying a standard of living today which is not at the expense of the standard of living that can be enjoyed by future generations (Pierre and Prothero, 1997). Charter (1992) mentioned that sustainability is at the nucleus of the green marketing philosophy. Van Dam and Apeldoom (1996) argued that the proactive elements of green marketing are being abandoned in favour of a responsive attitude, and environmental issues are converted from a societal challenge into a marketing 
problem. They indicated that sustainability as a social goal requires a change in virtually everyone's behaviour.

While environmental reform is a growing necessity at present, it is part of a bigger agenda in the urbanising world of developing countries. In Egypt, as the available natural resources must support a rapidly increasing population, sound management of such resources, together with a continuous improvement of the protection of the environment are evident necessities for sustainable development (MSEA, 2003; 2005). Economic development, urban strategy and environmental policy in Egypt continue along parallel tracks rather than in the integrated way demanded by sustainability (Zetter, and Hassan, 2002). Selman (2000) argued that although changes in individual attitudes and behaviours are important contributions to achieving sustainability, individual action alone cannot form the basis for collective action (Barry, 1999).

\section{THE STATE OF THE ENVIRONMENT IN EGYPT}

Motavalli (2005) indicated that Egypt is one of developing countries which are likely to be a drain on the Earth's dwindling resources and contribute to environmental degradation. This was supported by the MSEA (2004) report which indicates that Egypt is suffering from various extensive environmental problems such as air, water, soil, noise, and visual pollution, harmful waste disposal, desertification, land degradation, erosion of coastal zones and coral reefs, a change in the climate threatening agriculture, population explosion, and resulting several diseases such as vector borne diseases, physiological disorders, skin cancer, eye cataracts, deaths and injuries, respiratory ailments, heat strokes, and heat-related illnesses, as well as a weakening of the public health infrastructure (MSEA, 2005).

Although Egypt does not have an extensive history of environmental law, regulatory policy has gained momentum over the past few years. In 1994, Egypt passed Law 4 for the preservation of the environment (MSEA, 2003; 2005). Environmental policy in Egypt has always been reactive rather than proactive, pragmatic and uncoordinated over the past five decades, starting from the High Dam, moving on to the loss of agricultural lands, and most recently Cairo's black smog cloud in 1999. Policy design (whether urban or environment agendas) and weak institutional coordination can be diagnosed as endemic problems in Egypt. The physical size of Egypt, the enormous size and density of its urban population, and the role played by foreign assistance in determining its policy agendas, all contribute to 
major challenges in developing a coherent and effective environmental policy (Zetter and Hassan, 2002).

Egyptian citizens are also often effect changes themselves through cooperation with neighbours, thus bypassing the official channels of redress such as NGOs and local government officials (Hopkins et al., 2001). Bohlen (1994) argued that there may be certain country-specific factors such as different sources and types of pollution and their level of seriousness, environmental laws and legislation and the availability of green products which may affect the operationalisation of the environmental consciousness domain. Bohlen et al. (1993), Bohlen (1994), and Shlegelmilch et al. (1996) have concluded that the attitudinal component of the environmental domain is observed to be the most crucial predictor of green purchasing decisions. This view was supported by Rannikko (1996) who argued that changes in environmental attitudes constitute an important part of the change in environmental consciousness and that different citizens place different emphasis on environmental issues. Laroche et al. (2001) also emphasised that attitudes, as opposed to knowledge and behaviour, are the most significant predictors of consumers' willingness to pay more for environmentally-friendly products. Therefore, investigations are necessary to ascertain how Egyptian consumers' environmental attitudes are formed.

\section{ATTITUDE TOWARDS THE ENVIRONMENT}

Most researchers implicitly or explicitly view environmental concern as a general attitude that relates to consumers' cognitive and affective evaluation of the attitude object 'environmental protection' (Dunlap and Van Liere, 1978; Bamberg, 2003). Accordingly, environmental concern can be conceptualised as a general attitude that reflects the extent to which the consumer is worried about threats to the environment, the consequences of such threats for the harmony of nature and future generations, and the lack of human action to protect the environment for future generations (Bohlen et al., 1993; Bohlen, 1994; Diamantopolous et al., 2003; Mostafa, 2007a; 2007b).

An attitude towards the environment was used by Bohlen et al. (1993) and Bohlen (1994) as a unidimensionsal scale representing consumers' concern about the quality of the environment and reflecting the attitude towards key environmental issues. All factors included in the attitude scale appeared to capture the importance that individuals attributed to the environment. Therefore, it was decided to treat attitudes as a single conceptually meaningful dimension and purify the measure solely on the basis of internal consistency (Spector, 1992; Bohlen et al., 1993; Bohlen, 1994). Ellen (1994) also found that a general attitude towards improving the environment has 
been a significant predictor of recycling, source reduction, and political action. Therefore, companies aiming at increasing market penetration for their existing green product offerings would be advised to explore the consumers' concern about quality of the environment and to develop campaigns directed at increasing this level of concern (Bohlen et al., 1993).

\section{PROCEDURE}

For this paper, a large-scale structured survey was randomly distributed among Egyptian consumers. The Arabic version of the scale was created through accurate translation. These Arabic statements were back-translated into English by a bilingual expert. The translated version was cross-checked independently by another group of bilingual researchers. Then pilot testing including 50 respondents was carried out to ensure the reliability of the scale and allow for final adjustments. Stratified random sampling was used in this study. It combines the advantages of both probability and random samplings. Probability sampling is mainly used in quantitative studies with the aim of achieving representativeness and random sampling makes each sampling unit in a clearly defined population has an equal chance of being included in the sample. A total of 200 questionnaires were distributed across Egypt and a total of 122 consumers responded, resulting in $61 \%$ response rate. The questionnaire includes two sections. The first section includes the attitude scale and the second section includes demographics of the population. The attitude scale (see appendix) consists of thirtyeight five-point likert statements aimed at capturing the respondents' concern about environmental quality ( $1=$ "Strongly disagree," $5=$ "Strongly agree"). The thirty-eight attitude statements include: thirteen statements which were selected from the attitude scale of Bohlen et al. (1993) and Bohlen (1994) and which were proved to be highly reliable and valid; one statement which was selected from the New Environmental Paradigm Scale (NEP) of Dunlap et al. (2000); and twenty-four statements which resulted from the qualitative studies of Tantawi et al. (2006a; 2006b) and which explore Egyptian consumers' green consciousness and their opinion about the obstacles of going green in Egypt respectively.

\section{FINDINGS}

\section{Reliability of the Scale}

Reliability refers to the consistency of a measure of a concept (Bryman, 2004). It indicates how free a scale is from random error (Pallant, 2001). The reliability of the attitude scale was tested and resulted in a Cronbach's alpha 0.809. According to 
Bryman (2004, p.72), "the figure 0.80 is typically employed as a rule of thumb to denote an acceptable level of internal reliability". The result is shown in Table 1.

Table 1 Reliability Statistics

\begin{tabular}{cc}
\hline Number of Scale Items & Cronbach's Alpha \\
\hline 38 & .809 \\
\hline
\end{tabular}

\section{Demographic Profile of the Sample}

Table 2 illustrates the demographic profile of the sample. It can be noticed that the sample is a balanced one with respect to gender where males represent $50 \%$ and females represent $50 \%$. Age is constituted by: youth who represent $56.5 \%$ of the sample and which includes those who are below $21(18.0 \%)$ and those between 21 and 30 (38.5\%); middle age respondents who represent $23.0 \%$ of the sample; and elders who represent $20.5 \%$ of the sample. Respondents with high educational level (university graduate, post graduate or professional degree) represent $68.9 \%$ of the sample. Those with above medium educational level represent $11.5 \%$ of the sample, and those with medium educational level represent $19.7 \%$. Respondents exhibit different household income levels where $48.3 \%$ have high income level (more than L.E. 35,000 and from L.E. 25,000 to 35,000 yearly), $16.4 \%$ have above average income level (from L.E. 15,000 to 25,000 yearly), $20.5 \%$ have average income level (from L.E. 5,000 to 15,000 yearly) and $14.8 \%$ have low income level (less than L.E. 5,000 yearly).

Figure 1 shows that the majority of respondents have a positive attitude towards the environment i.e. they have a high level of concern about quality of the environment. They represent $67.21 \%$ of the sample. Respondents who do not show a positive or a negative attitude towards the environment represent $31.97 \%$. However, those who have low or almost no concern about the quality of the environment are only $0.82 \%$ of the sample. Table 3 illustrates these results. 
Table 2 Demographic Characteristics of the Sample (N)

\begin{tabular}{|c|c|c|c|c|}
\hline Demographics & $\begin{array}{c}\begin{array}{c}\text { Number of } \\
\text { cases }\end{array} \\
\end{array}$ & Classification & Frequency & Percent \\
\hline \multirow{4}{*}{ Age } & \multirow{4}{*}{122} & below 21 & 22 & 18.0 \\
\hline & & $21-30$ & 47 & 38.5 \\
\hline & & $31-40$ & 28 & 23.0 \\
\hline & & Above 40 & 25 & 20.5 \\
\hline \multirow{2}{*}{ Gender } & \multirow{2}{*}{122} & Male & 61 & 50.0 \\
\hline & & Female & 61 & 50.0 \\
\hline \multirow{5}{*}{$\begin{array}{l}\text { Educational } \\
\text { level }\end{array}$} & \multirow{5}{*}{122} & High school & 19 & 15.6 \\
\hline & & IGCSE or Equivalent & 5 & 4.1 \\
\hline & & Two years after school & 14 & 11.5 \\
\hline & & university graduate & 60 & 49.2 \\
\hline & & post graduate or professional degree & 24 & 19.7 \\
\hline \multirow{5}{*}{$\begin{array}{l}\text { Household } \\
\text { income }\end{array}$} & \multirow{5}{*}{122} & less than 5000 & 18 & 14.8 \\
\hline & & $5000-15,000$ & 25 & 20.5 \\
\hline & & $15,000-25,000$ & 20 & 16.4 \\
\hline & & $25,000-35000$ & 12 & 9.8 \\
\hline & & more than 35,000 & 47 & 38.5 \\
\hline
\end{tabular}

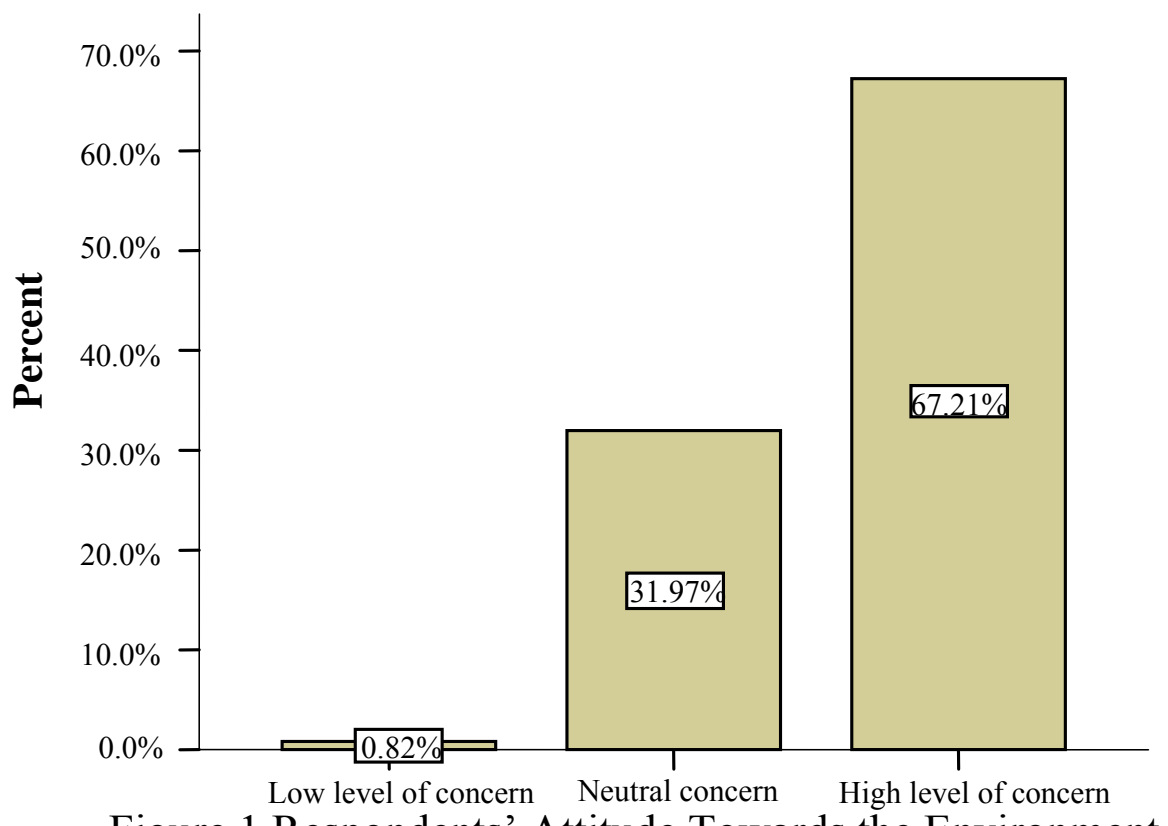

Figure 1 Respondents' Attitude Towards the Environment 
Table 3 Respondents' Attitude Towards the Environment

\begin{tabular}{lcc}
\hline \multicolumn{1}{c}{ Levels of concern } & Frequency & Percent \\
\hline Low concern & 1 & 0.82 \\
\hline Neutral concern & 39 & 31.97 \\
\hline High concern & 82 & 67.21 \\
\hline Total & 122 & 100.0 \\
\hline
\end{tabular}

\section{Testing the Hypothesis}

One sample t-test is used to examine the minority and majority of respondents' answers concerning specific variable(s) and tests the hypothesis about a mean (Lind et al., 2002). It is used to test the following hypothesis:

Ho: $\mu \geq 2$ Egyptian consumers have positive attitude towards the environment i.e. they have high concern about the quality of the environment.

H1: $\mu<2$ Egyptian consumers have negative attitude towards the environment i.e. they have low or no concern about the quality of the environment.

Results of the one sample t-test are presented in Table 4. They indicate accepting the null hypothesis because the calculated t-value (14.923) is greater than the tabulated t-value $(-1.645)$ at confidence level $95 \%$ and $.5759 \leq \mu-2 \leq .7520$ will yield a $\mu$ which is greater than 2 (test value). Hence, Egyptian consumers exhibit positive attitude (which varies between medium to high levels of concern) towards their environment. They are concerned about the quality of the environment.

Table 4 Results of One Sample T-test

\begin{tabular}{|c|c|c|c|c|c|c|}
\hline \multicolumn{7}{|c|}{ Test value $=2$} \\
\hline & \multirow[t]{2}{*}{$\begin{array}{l}\text { Number of } \\
\text { cases }\end{array}$} & \multirow[t]{2}{*}{$\mathrm{T}$} & \multirow[t]{2}{*}{$\begin{array}{c}\text { Sig. } \\
\text { (2tailed) }\end{array}$} & \multirow[t]{2}{*}{$\begin{array}{c}\text { Mean } \\
\text { Difference }\end{array}$} & \multicolumn{2}{|c|}{$\begin{array}{l}95 \% \text { Confidence } \\
\text { Interval of the } \\
\text { Difference }\end{array}$} \\
\hline & & & & & Lower & Upper \\
\hline $\begin{array}{l}\text { Attitude towards the } \\
\text { Environment }\end{array}$ & 423 & 14.923 & .000 & .65012 & .5759 & .7520 \\
\hline
\end{tabular}




\section{DISCUSSION}

Unlike western consumers, Egyptian consumers are just at the stage of green awakening. In fact, little research in the field of green marketing has been conducted concerning cross-cultural studies on environmental attitudes (Laroche et al., 2001; 2002) in an Arab non-western context (Mostafa, 2007a; b). Therefore, this research empirically tested Egyptian consumers' attitude towards the environment in general because attitude is considered to be the most crucial predictor of green purchasing decisions (Bohlen et al., 1993; Rannikko, 1996; Shlegelmilch et al., 1996; Laroche et al., 2001).

A survey was developed and piloted to ensure its reliability and applicability within the Egyptian context. Stratified random sampling was used in this study. It is the outcome of both probability and random samplings techniques. Stratified random sampling includes all important subpopulations and hence increases precision (Tashakkori and Teddlie, 2003; Bryman, 2004; Teddlie and Yu, 2007). The attitude scale included statements from Bohlen et al. (1993) and Bohlen (1994) attitude scale, Dunlap et al. (2000) New Environmental Paradigm Scale (NEP) and the results of the qualitative studies of Tantawi et al. (2006a; b). The findings indicated that Egyptian consumers have positive attitude towards the environment. Such results support Mostafa's (2007a) and Hopkins et al. (2001) findings which indicated that consumers are concerned about the quality of the environment but they rank their economic concerns prior to environmental concerns (Hopkins et al., 2001; Tantawi et al., 2006a; b). On the other hand, findings contradict previous research that have been conducted in the West and which rely on the traditional wisdom that environmental concern is a luxury afforded by only the wealthy.

However, Egyptian consumers do not consider going green to be one of their priorities and they may take anti-environmental actions (Tantawi et al., 2006b), they have positive attitude towards their environment. This could be attributed to the obstacles of going green in Egypt (Tantawi et al., 2006b) i.e. the fact that Egyptian consumers' are pressured by economic conditions (such as corruption), perceive the environment to be polluted and would like to do something but can not combat pollution without the help of the government. This could be a logical explanation because support for environmental protection does not necessarily lead to environmentally friendly consumption and life style (Rannikko, 1996). The findings come in support with the study of Tantawi et al. (2006b) where Egyptian consumers argued that protecting and preserving the environment is the responsibility of every citizen however the larger responsibility falls on the government part. Egyptian 
consumers urge the government to be green-oriented in order that they go green (Tantawi et al., 2006b). The Egyptian government and policy makers have to include overcoming the obstacles of consumers' going green in their strategic planning and institutionalise such environmental policies and strategies to motivate consumers to go green.

Understanding the issues involved in green consciousness will necessarily influence the way marketers segment the consumer market and the way they position products or services linked to green issues. This allows marketers to develop green strategies and tailor green marketing messages that hedonically and functionally appeal to green consumers in Egypt. According to the findings of the present study, consumers are concerned about the environment. Thus, designing messages to educate consumers about various pro-environmental behaviours such as recycling and safe waste disposal options and joining green organisations will encourage them to put their concern into action. Moreover, campaigns to promote green products should convey the message that consumer's actions make a difference. Ottman et al. (2006) argued that companies should avoid the common pitfall of green marketing myopia where companies just produce green products which do not appeal environmentally preferable to consumers because they do not offer additional features or new styles that are desired by consumers. Green marketers could educate consumers about the convenience of buying green products in order to develop positive attitude based on that knowledge.

\section{CONCLUSION}

Egypt is experiencing multiple environmental problems and consumers are just starting to urge the need for going green (Hopkins et al., 2001; Motavalli, 2005; MSEA, 2005; Tantawi et al., 2006a; b). Although, the Egyptian government has put environmental issues towards the top of the agenda for future policy making, Egyptian consumers consider that government's efforts towards preserving the environment are insufficient and that environmental laws and policies are poorly communicated and enforced (Hopkins et al., 2001; Tantawi et al., 2006a; b).

Although this study helps in providing an understanding of the general attitude of Egyptian consumers towards the environment, it has been cross-sectional in nature. This implies that much more emphasis has been placed on observing consumers' green consciousness than on observing changes in this consciousness. Longitudinal studies, in particular, are needed to understand the development of green consciousness in Egypt, its stability across the life span, the effect of segmentation 
variables (such as personality variables) on consumers' green consciousness, and how this consciousness is related to cognitive, moral and social development (Zelezny et al., 2000). Hume (1991) concluded that although many consumers say they are proenvironment, they often do not act that way. Therefore, future research should investigate whether or not Egyptian consumers' positive environmental attitude is reflected in their behaviour and whether they are willing to purchase goods based solely on environmental grounds (Mostafa, 2007b).

Pro-environmental attitude was captured in this study as a unidimensional scale rather than as composed of specific pro-environmental attitudes. Attitude is the most significant predictor of environmentally sensitive behaviour (Bohlen et al., 1993; Schlegelmilch et al., 1996; Diamantopoulos et al., 2003), if captured as a multidimensional scale (Ajzen and Fishbein, 1980). Then, future research is required to explore consumers' specific attitudes towards the environment and their links with pro-environmental behaviours and to segment consumers based on the different dimensions of pro-environmental attitude.

The present study reveals the importance of future research in exploring the role of government in going green and its effect on consumers' green consciousness. Furthermore, it is needed to explore the reasons behind the widened gap between the existence of environmental laws and policies and their real enforcement in Egypt. Such research will call for the inclusion not only of consumer behaviour studies but also of different fields in Egypt such as public policy, green strategic marketing, and sustainable development. In order to determine the generalisability of the results of this study, future research should consider cross-cultural studies, especially in the Middle East because there are country specific factors which may have impact on the measures of green consciousness and factors affecting them (Furman, 1998).

\section{REFERENCES}

Abdul-Muhmin, A.G. (2007). Explaining Consumers' Willingness to Be Environmentally Friendly. International Journal of Consumer Studies, 31(3), 237-247.

Ajzen, I., \& Fishbein, M. (1980). Understanding Attitudes and Predicting Behaviour. Englewood Cliffs. NJ: Prentice Hall.

Azzone, G., \& Bertele, U. (1994). Exploiting Green Strategies for Competitive Advantage. Long Range Planning, 27(6), 69-81.

Bamberg, S. (2003). How Does Environmental Concern Influence Specific Environmentally Related Behaviours? : A New Answer to an Old Question. 
Journal of Environmental Psychology, 23, 21-32.

Barry, J. (1999). Rethinking Green Politics. London: Sage Publications.

Beaumont, J.R., Pedersen, L.M., \& Whitaker, B.D. (1993). Managing the

Environment: Business Opportunity and Responsibility. Oxford: ButterworthHeinemann Ltd.

Bohlen, G. M., M. (1994). Environmental Consciousness: The Construct and Its Application in an Industrial Setting. Swansea: A dissertation submitted to European Business Management School, University of Wales.

Bohlen, G., Schlegelmilch, B.B., \& Diamantopoulos, A. (1993). Measuring Ecological Concern: A Multi-Construct Perspective. Journal of Marketing Management, 9, 415-430.

Brunner, B. (2006). Tsunami Factfile: Special Report. Retrieved September 9, 2006, from http://www.livescience.com/forcesofnature/tsunami_special_report.html.

Bryman, A. (2004). Social Research Methods. US: Oxford University Press, 2nd ed..

Buttel, F.H. (1992). Environmentalisation: Origins, Processes, and Implications for Rural Social Change. Rural Sociology, 57, 1-27.

Charter, M. (1992). Greener Marketing: A Responsible Approach to Business. Sheffield England: Greenleaf Publishing.

Charter, M., \& Polonsky, M. (1999). Greener Marketing: A Global Perspective on Greening Marketing Practice. Sheffield: Greenleaf.

Clark, C. F., Kotchen, M. J., \& Moore, M. R. (2003). Internal and External Influences on Pro-Environmental Behaviour: Participation in A Green Electricity Program. Journal of Environmental Psychology, 23, 237-246.

Coddington, W. (1993). Environmental Marketing: Positive Strategies for Reaching the Green Consumer. London: McGraw-Hill.

Diamantopoulos, A., Schlegelmilch, B.B., Sincovics, R. R., \& Bohlen, G. M. (2003). Can Socio-Demographics Still Play a Role in Profiling Green Consumers? A Review of the Evidence and Empirical Investigation. Journal of Business Research, 56, 465-480.

Dunlap, R., \& Van Liere, K. (1978). The New Environmental Paradigm: A Proposed Measuring Instrument and Preliminary Results. Journal of Environmental Education, 9, 10-19.

Dunlap, R. E., Van Liere, K. D., Mertig, A. G., \& Jones, R. E. (2000). Measuring Endorsement of the New Ecological Paradigm: A Revised NEP Scale. Journal of Social Issues, 56(3), 425-442.

Ellen, O.S. (1994). Do We Know What We Need To Know? Objective And 
Subjective Knowledge Effects on Pro-Ecological Behaviours. Journal of Business Research, 30, 43-52.

Fuller, D.A. (1999). Sustainable Marketing: Managerial-Ecological Issues, Thousand Oaks. CA: Sage Publications.

Furman, A. (1998). A Note on Environmental Concern in a Developing Country:

Results from an Istanbul Survey. Environment and Behaviour, 30(4), 520-534.

Graham, C. (1994). The Mass Media and Global Environmental Learning. Retrieved

June 6, 2006, from http://www.sussex.ac.uk/units/gec/ph2summ/chapman2.htm.

Green Peace International (2006). Year One of the Prestige Oil Spill: A decade of Destruction Still to Come. Retrieved September 5, 2006, from http://www.greenpeace.org/international/news/prestige-one-year-on.

Hopkins, N. S., \& Mehanna, S. R. (2000). Social Action against Everyday Pollution in Egypt.. Human Organization, 59(2), Summer, 245-254.

Hopkins, N. S., Mehanna, S. R. and El-Haggar, S. (2001). People and Pollution:

Cultural Constructions and Social Action in Egypt. Cairo: American University in Cairo Press.

Hume, S. (1991, October 28). Consumer Doubletalk Makes Companies Wary. Advertising Age, 62(46), GR4.

Infoplease. (2006). Major Earthquakes around the World. Retrieved September 5, 2006, from http://www.infoplease.com/ipa/A0933317.html.

Inglehart, R. (1990). Cultural Shift in Advanced Industrial Society. Princeton, NJ: Princeton University Press.

Karna, J., Hansen, E., \& Juslin, H. (2003). Social Responsibility in Environmental Marketing Planning. European Journal of Marketing, 37, 61-65.

Laroche, M., Bergeron, J., \& Barbaro-Forleo, G. (2001). Targeting Consumers Who Are Willing to pay more for Environmentally-Friendly Products. Journal of Consumer Marketing, 18(6), 503-520.

Laroche, M., Bergeron, J., Tomiuk, M., \& Barbaro-Forleo, G. (2002). Cultural Differences in Environmental Knowledge, Attitudes, and Behaviours of Canadian Consumers. Canadian Journal of Administrative Sciences, 19(3), 267283.

Lee, C., Barnowe, J. T., \& McNabb, D. E. (2005). Environmental Perceptions, Attitudes and Priorities: Cross-Cultural Implications for Public Policy. Cross Cultural Management, 12(1), 61-83.

Lind, D. A., Marchal, W. G., \& Mason, R. D. (2002). Statistical Techniques in Business and Economics, 11th ed.. NY: McGraw-Hill-Irwin. 
MacKenzie, D. (2000, 10th of January). You Can Still Shop to Save the World. New Statesmen, 129(4468), Special supplement, 12-14.

Menon, A., \& Menon, A. (1997). Enviropreneurial marketing strategy: the emergence of corporate environmentalism as market strategy. Journal of Marketing, 61, 5167.

Meyer, H. (2000). The Greening Corporate of America. Journal of Business Strategy, January-February, 21(1), 38-43.

Ministry of State for Environmental Affairs (MSEA), Egyptian Environmental Affairs Agency (EEAA), Country Analysis Briefs, Environmental International Agency. August (2003). Egypt: Environmental issues. Retrieved December 15, 2005, from http://www.eia.doe.gov/emeu/cabs/egypenv.html.

Ministry of State for Environmental Affairs (MSEA), Egyptian Environmental Affairs Agency (EEAA), Egypt State of the Environment Report 2004. 2005. Review of Policies and the State of Environment in Egypt. May, 1-95.

Mostafa, M. M. (2007a). Gender Differences in Egyptian Consumers' Green Purchase Behaviour: The Effects of Environmental Knowledge, Concern and Attitude. International Journal of Consumer studies, 31, 220-229.

Mostafa, M. M. (2007b, May). A Hierarchical Analysis of the Green Consciousness of the Egyptian Consumer. Psychology and Marketing, 24(5), 445-473.

Motavalli, J. (2005, Sep-Oct). Cities of the Future: Today's "Mega-cities" are Overcrowded and Environmentally Stressed. CT, US: The Environmental Magazine.,.

Ottman, J. A. (1998). Green Marketing: Opportunity for Innovation. 2nd ed., Chicago, IL: NTC Business Books.

Ottman, J. A., Stafford, E. R., \& Hartman, C. L. (2006, June). Avoiding Green Marketing Myopia: Ways to Improve Consumer Appeal for Environmentally Preferable Products. Environment: Science and Policy for Sustainable Development, 48(5), 22-36.

Paladino, A. (2005, March). Understanding the Green Consumer: An Empirical Analysis. Journal of Customer Behaviour, 4(1), 69-102.

Pallant, J. (2001). SPSS Survival Manual: A Step by Step Guide to Data Analysis: Using SPSS for Windows. U.S.: Open University Press.

Peattie, K. (1992). Green Marketing, The M\&E Handbook series. London, UK: Pitman Publishing.

Peattie, K. (1995). Environmental Marketing Management: Meeting the Green Challenge. London: Pitman Publishing Company. 
Peattie, K., \& Crane, A. (2005). Green marketing: legend, myth, farce or prophesy?. Qualitative Market Research: An International Journal, 8(4), 357-370.

Pierre, M., \& Prothero, A. (1997). Green management: A Reader. London: the Dryden Press.

Polonsky, M. J., \& Rosenberger III, P. J. (2001, September-October). Re-evaluating Green Marketing: A Strategic Approach. Business Horizons , 44(5), 21-30.

Prothero, A. (1990). Green Consumerism \& the Societal Marketing ConceptMarketing strategies for the 1990s. Journal of Marketing Management, 6(2), 87103.

Rannikko, P. (1996). Local Environmental Conflicts and the Change in Environmental Consciousness. Acta Sociologica, 39(1), 57-72.

Rice, G. (2006). Pro-environmental Behaviour in Egypt: Is there a Role for Islamic Environmental Ethics?. Journal of Business Ethics, 65, 373-390.

Saha, M. \& Darnton, G. (2005). Green Companies or Green Con-panies: Are Companies Really Green, or Are They Pretending to be?. Business and society Review, 110(2), 117-157.

Schlegelmilch, B.B., Bohlen, G.M., \& Diamantopoulos, A. (1996). The Link between Green Purchasing Decisions and Measures of Environmental Consciousness. European Journal of Marketing, 30(5), 35-55.

Selman, P. (2000). A Sideways Look at Local Agenda 21. Journal of Environmental Policy and Planning, 2, 39-53.

Shamdasani, P., Chon-Lin, G., \& Richmond, D. (1993). Exploring Green Consumers in an Oriental Culture: Role of Personal and Marketing Mix. Advances in Consumer Research, 20, 488-493.

Shelth, J. N., Mittal, B., \& Newman, B. I. (1999). Customer Behaviour: Consumer Behaviour and Beyond. Fort Worth: the Dryden Press.

Shrum, L. J., McCarty, J. A. \& Lowery, T.M. (1995). Buyer Characteristics of the Green Consumer and Their Implications for Advertising Strategy. Journal of Advertising, summer, XXIV (2), 71-82.

Spector, P. R. (1992). Summated Rating Scale Construction: An Introduction. Quantitative Applications in the Social Sciences, Series no. 07-082. Newbury Park, California: Sage.

Sudarmadi, S., Suzuki, S., Kawada, T., Netti, H., Soemantri, S., \& Tugaswati, A. (2001). A Survey of Perception, Knowledge, Awareness, and Attitude In Regard To Environmental Problems in a Sample of Two Different Social Groups in Jakarta, Indonesia. Environment, Development, and Sustainability, 3, 169-183. 
Tantawi, P., O'Shaughnessy, N., \& Gad, K. (2006a, July 10-13). Exploring Environmental Consciousness among the Egyptian Consumers. Paris, France: paper presented at Academy of World Business, Marketing and Management Development Conference.

Tantawi, P., O'Shaughnessy, N., \& Gad, K. (2006b, July 12-14). Obstacles of Going Green in Egypt. Singapore: paper presented at International Conference on Business and Information.

Tashakkori, A., \& Teddlie, C. (2003). Handbook on Mixed Methods in the Behavioral and social sciences. Eds., Thousand Oaks. CA: Sage Publications.

Teddlie, C., \& Yu, F. (2007). Mixed Methods Sampling: A Typology with Examples. Journal of Mixed Methods Research, January, 1(1), 77-100.

UN, Chronicle (2002, December). Global warming challenges African development: Eightfold Rise in [CO.sub.2] in Fifty Years. United Nations Environment Programme: United Nations Publications.

Van Dam, Y., \& Apeldoom, P. (1996). Sustainable Marketing. Journal of Macromarketing, 16(2), 45-56.

Vandermerwe, S., \& Oliffe, M. D. (1990). Customers Drive Corporations Green. Long Range Planning, 23(6), 10-16.

Wagner, S. A. (1997). Understanding Green Consumer Behaviour: A Qualitative Cognitive Approach. London and New York: Routledge.

Zelezny, L.C., Chua, P., \& Aldrich, C. (2000). Elaborating on Gender Differences in Environmentalism. Journal of Social Issues, 56(3), 443-457.

Zetter, R., \& Hassan, A. M. (2002). Urban Economy or Environmental Policy? The Case of Egypt. Journal of Environmental Policy \& Planning, 4(2), 169-184.

Zimmer, M. R., Stafford, T. F., \& Stafford, M. R. (1994, May). Green Issues: Dimensions of Environmental Concern. Journal of Business Research, 30(1), 6374. 


\section{APPENDIX - ATTITUDE STATEMENTS}

1. The increasing deterioration of the environment is a serious problem.

2. If all of us, individually, made a contribution to environmental protection, it would have a significant effect.

3. The government should take responsibility for environmental protection.

4. We should pay a considerable amount of money to preserve our environment.

5. The environmental policies of the main political parties are one issue I consider when deciding how to vote.

6. The environment is one of the most important issues facing the Egyptian society today.

7. Everyone is responsible for protecting the environment in their everyday life.

8. Strict global measures must be taken immediately to stop environmental decline.

9. The benefits of protecting the environment do not justify the expense involved*.

10. We should recognise the need to protect the environment today so that future generations will not suffer the consequences.

11. Citizens should recycle their household waste.

12. Firms should provide a wide array of green products in the market.

13. Preserving and protecting the environment should be one of our priorities.

14. The importance of the environment is frequently exaggerated*.

15. Firms should always put profitability before environmental protection*.

16. The government should subsidise research on technology for recycling waste products.

17. Religious institutions should use religion as a tool to raise environmental awareness.

18. The government should provide us first with employment opportunities before focusing on preserving the environment.

19. The government should enforce environmental rules and regulations.

20. Environmental issues are very important to me.

21. Citizens should urge their neighbours and friends not to use products that pollute the environment.

22. Recycling should be another option for waste disposal other than the garbage bin.

23. The government should first enhance citizens' standard of living before focusing on preserving the environment. 
24. Personally, I have economic concerns which I consider more important than preserving the environment*.

25. If things continue on their present course, we will soon experience a major environmental catastrophe in Egypt.

26. We should do our best efforts to save scarce natural resources from being used up.

27. It genuinely infuriates me that the government does not provide more help to control pollution of the environment.

28. Using environmentally-friendly products is for luxury and showing-off not for protecting the environment*.

29. I would accept paying extra price for environmentally-friendly products to preserve our environment.

30. I trust that companies producing environmentally friendly products are really providing environmentally safe products.

31. Products which pollute the environment during manufacturing or consumption should be heavily taxed by the government.

32. The religious leaders should educate citizens how protecting the environment is important in religion.

33. Parents should raise and educate future generations to care about preserving the environment.

34. Schools should require all students to take a course dealing with environment and conservation problems.

35. The government should communicate environmental rules and regulations to the public through the media.

36. Industries should recycle their wastes to protect the environment

37. It is the duty of the media to provide accurate information about the real state of environmental problems

38. We should preserve our environment because it is one of the important mandates in religion 